\title{
A study on the impact of Job Satisfaction on Job Performance of Employees working in Automobile Industry, Punjab, India
}

\author{
Shaju.M \\ Bharathiar University, Coimbatore
}

Subhashini.D

PhD Research Scholar, Anna University, Chennai

$\begin{array}{lrr}\text { Received: Sep. 6, } 2016 & \text { Accepted: Dec. 16, } 2016 & \text { Published: January 1, } 2017 \\ \text { doi:10.5296/jmr.v9i1.10420 } & \text { URL: http://dx.doi.org/10.5296/jmr.v9i1.10420 }\end{array}$

\begin{abstract}
Performance evaluation is a major measure adopted by the organizations in evaluating the quantitative and qualitative contributions rendered by their employees. The competitive and employee oriented business world has now joined hands with the HR department in assisting and managing employee performance. Psycho-social factors of employees would be considered at various managerial levels for enhancing employees' job performance. Job satisfaction is such a psychological attribute, whose contribution to the concept of employee performance is much more. A satisfied employee would have an emotional bond with the organization and takes pride in their membership, which paves way to keep up industrial integrity and a high morale. This is an exploratory research, attempting to discover how the dimensions of job satisfaction are significantly related to the job performance of an employee. The data were collected from employees working in Automobile industry, Punjab having experience of above or below 10 years, so as to ensure relatively accurate responses on performance evaluation at different groups of employees in the Automobile industry. The result shows the existence of a positive correlation between the dimensions of job satisfaction and performance of employees at both supervisors and workers levels working in the Automobile industry.
\end{abstract}

Keywords: Performance Evaluation, Job Performance, Job Satisfaction, Automobile Industry, Performance Management System. 


\section{Introduction}

\section{Background of the study}

The term Job satisfaction is furnished as the attitude of content, an employee possesses in his or her current position in an organization. In the last few decades, a number of scholarly studies have been conducted using the workers' satisfaction as a central research variable. It has to be regarded as an obligatory attribute which is very frequently measured by organizations in order to ensure the existence of an affectionate approach of employees towards the duties and responsibilities they deal with. Despite of the world-wide urges for considering employees as a human asset of the organization, the prevailing scenario of profit oriented business is neither providing a fair remuneration system nor extending welfare oriented move towards its employees, often. Therefore, the turnover rate has alarmingly increased in most of the industries in all the levels of employments. Here comes the significance of guaranteeing a level headed state of job satisfaction among the employees of any organization, which in turn may land in organizational effectiveness.

Zain, Ishak and Ghani (2009) illustrate the factor of job satisfaction as being constituted of by employees' thoughts, feelings, interactions and performance. On the basis of Hawthorne studies, Glenn Bassett (2004) articulates the working hypothesis of the human relations movement in management has consistently proposed that the satisfied worker is a productive one. Over the recent years, researches are moving in the reverse direction, inferring that employee performance influences job satisfaction (Bassett, 2004: 1).

(Locke, 1976; Spector, 1997) defines Job satisfaction as nothing but a positive emotional state resulting from the pleasure a worker derives from the job. (Kalleberg, 1977; Mercer, 1997; Wright and Cropanzano, 1997; Wong et.al., 1998) treats Job satisfaction as the attitude, both affective and cognitive, being possessed by an employee in respect of the whole aspects of their work, the latter implying that satisfaction is related to the component facets rather than the whole job, which is consistent, Spector (1997).

\section{The Concept of Job Satisfaction}

During the earlier stages of researches, efforts were made to correlate job performance with job satisfaction and it came out with the complementary nature of these entities each other, implying a positive correlation among them. But later on, some studies revealed that good job performance leads to higher job satisfaction, however the reverse found non-significant. Evaluating the performance of an employee in an organization is not only having concern with how much satisfied he is with the job, but also with so many other factors like his professional independence, organizational commitment, emotional intelligence, disciplined nature, collaborative working style, organizational citizenship behavior, etc. Job satisfaction is a psychological attribute of the employee which he enjoys, whereas, job performance is the practical reflection of that employee's aptness to that profession, which make the employer rejoice.

It is observed that the level of job satisfaction is determined by four main groups of factors like economic aspects, interpersonal relations, working conditions and personal fulfillment, 
including pay, working hours, working conditions, Human Resource department, job design, stress and various demographic factors.

Job satisfaction is the most considerable factor in understanding the worker motivation, effectiveness, retention and performance. It's a pleasurable, positive state resulting from one's job and job experiences (Bashayreh, 2009). In addition to the specific task environment of the employees, this also encircles the individual's affective attitude or orientations for work (Bashayreh, 2009: 7). Enhanced level of job performance, positive work values, high levels of employee motivation, lower rates of absenteeism, turnover and burnout are the positive impacts of job satisfaction (Ngo, 2009). Notwithstanding such constructive outcomes, an unsatisfied employee may cause undesirable job outcomes through low productivity, stealing, moonlighting and demonstrating high rates of absenteeism. These aspects would subsequently insist the employee for a passive withdrawal from the organizational affairs. In managerial perspective, the satisfied workforce translates into higher productivity due to their better psychological well being and fewer destructive interruptions in the area of performance (Van Der Zee, 2009).

The factors affecting employees' job satisfaction are intrinsic and extrinsic factors, personal attributes and work environment. The argument that employee satisfaction improves service quality is grounded on the theory of equity in social exchanges, involving a series of interactions to generate obligations that are unspecified (Zafirovski, 2005: 1-2).

\section{Statement of the problem}

Organizations at this cutthroat epoch, is in a strong intention of hiring of and retaining the most suitable employees. In order to accomplish this purpose, performance evaluation has become a strong necessity for both the employees and employers in different senses. On evaluating employees in consonance with their professional and social aspects, numerous psychological and behavioral features are also to be accounted into. In a competitive business environment prevails all over the globe, this process of evaluation has emerged into a superior dimension of assisting and managing the performance of employees. This approach invariably estimates the worthy contributions of an employee on the whole and thereby acknowledges the imperative relationship of performance with employees' psychological factors like job satisfaction, emotional intelligence, organizational citizenship behavior, work motivation, professional integrity, etc.

This research tries to identify the impacts of job satisfaction dimensions on job performance of employees of the Automobile Industry. It investigates the relationship between the dimensions of job satisfaction and the job performance of the respondents and thereby to cross check whether the former influences the latter in a positive sense or not.

\section{Objectives of the study}

The main objective of the study is to investigate the impact of job satisfaction level of the respondents on their respective performance evaluation results. 
Also the study tries to find out the relationship between the JS factors and the performance evaluation results of the respondents.

The study sought to answer the following research questions.

1. What is the impact of JS and its dimensions on Job Performance of the employees?

2. What is the relationship between JS level of employees and their respective performance evaluation results?

\section{Contributions of the Study}

This study would contribute additionally to the existing knowledge in the field of performance evaluation based on job satisfaction of the employees in the organizations. The study is focused on the employees working in Automobile Industry, Jalandhar, Punjab. Such a study provides them adequate knowledge on the concept of job satisfaction and would further help to understand its impact on job performance of the employees. This study also serves as a source of reference to other types of organizations also, who wants to measure and manage the Job Satisfaction level of their employees which have a positive impact on their Job performance.

\section{Literature Review}

According to the researches' outputs available so far, job satisfaction level is exposed maximum in the jobs like Physical Therapists, Authors, Psychologists, Fire fighters, Teachers, Educational Administrators, Painters, Sculptors, etc. The professions where the job satisfaction is observed with least significance are Laborers (excluding those in construction field), Clothing salespersons, Furnishing Salespersons, Packagers, Food preparers, Food servers and material handlers, etc. (Schultz D, 2010.)

Evidently, job satisfaction, is been constituted with numerous facts and the major dimensions to this regard are pay, the work itself, promotions, supervision, work group, and working conditions mentioned in a study about the relationship in between job satisfaction and job performance has a controversial history (Luthans 1985). Saari and Judge (2004: 395). Soon after the disposals by the Hawthorne studies, the world wide researchers interpreted the happy worker, as a productive worker. In the earlier days of researches, a weak or somewhat inconsistent relationship was presumed in between job satisfaction and performance.

An employee stayed back in an organization for a long tenure was observed as investing mentally and physically in a better manner rather than a younger employee. Extensive researches could thereby prove a positive correlation between professional experience and job satisfaction (Lim and Teo, 1998). Even though the same inference could be matched up by the research of Smith et al, (1969), he could also conclude at the fact of highest satisfaction experienced by the workers with an experience of less than six months. In his study, Morgan et al (1995) brought to a close that there is a correlation between these two variables and job satisfaction seems to be greatly reduced in the older employees with many years of professional experience. 
Another important demographic feature is the hierarchical level to which the employee belongs. According to the researches people who work at higher levels of management are more satisfied. Oshagbemi (1997) observed a positive correlation between job satisfaction and the hierarchical level to which an employee belongs to. In 2003, O Pors reached the same attention-grabbing end of finding a lesser degree of satisfaction among the lower tier employees, and the reasons being the lack of freedom and autonomy.

According to Skibba (2002) the underlying theory of reciprocal model is that if the satisfaction is extrinsic in nature, then it leads to performance, and the performance leads to satisfaction, in case of an intrinsic quality in satisfaction. Also she speaks about the relationship in between job performance and job satisfaction as a follow up of social exchange theory, in which the job performance is to be regarded as a return by the employee to the organization from which they get their satisfaction. This study also reminds that, to the best of industrial psychologists' belief, there is no relationship between job satisfaction and job performance; although it is revealed that a positive mood would lead to higher levels of both the features.

A survey was conducted in 2006 on 7939 business units in 38 countries and showed that customer satisfaction, profitability, turnover of staff and less work mishaps were due to a higher satisfied and engaged staff (Norwack, 2006). In a research by Woodruffe \& Lockwood (2006), an engaged and a satisfied employee, most probably would be an organizationally committed one and he or she tends to be the top performer of the organisation always. When an employee is engaged they serve customers better and therefore contribute more to the organization's ongoing profitability.

Alina Hyz (2010) argues points out the lack of correlation between the demographic characteristics such as age, gender, years of experience and educational level of respondents. These variables are independent of each other, whereas exception exists in employee's position in the organization and access to organizational decision making. As long as the enhancement in the position of an employee occurs, his or her satisfaction from the job also increases, due to greater benefits, autonomy, more creative works etc. Also, it is observed that well-educated employees are characterized significantly by a lower state of satisfaction with respect to their salary. Recognition, autonomy, working with groups, prospects, clarity of responsibilities, relationships with co-workers and cooperation with the department of human resources are those factors showing a positive correlation with job satisfaction with a considerable varying intensity.

In a survey conducted by Anuar Bin Hussin in Trade winds Group of Companies in Klang Valley, it made known a positive relationship between job satisfaction components which were promotion, work itself, supervision and co-workers except for pay towards employee job performance. Also the study noted a significant difference between position and job performance. The job satisfaction dimensions, like pay, promotion, work itself, supervision and co-workers can surely contribute to 17.8 percent increase the job performance in the organization. Syaidatulakma binti bahani (2013) comes out with an inference matching to the same, among job performance and aforesaid dimensions. 
Dr. Padmakumar Ram (2013) wraps up after a public sector study in India, as no association between job facet satisfaction and overall job satisfaction. Out of the six measures of job performance, the single one which reflected a noticeable concern with overall job satisfaction was 'passenger complaints'. No association was found between salary and overall job satisfaction, in the case of low and medium income groups. Nevertheless, for high income groups, a negative association between these entities could observe.

By using a model that incorporates the main constructs from agency theory and organizational psychology, Markus Christen, Ganesh Iyer \& David Soberman (2006), finds a negative, direct effect of effort and a positive, direct effect of job performance on job satisfaction. Conflicting findings in the earlier researches are argued as the result of inconsistency in both the measurement and the definition of constructs across studies that do not fully account for all the relationships between constructs. Here comes the need to distinguish clearly between factors that represent employees' inputs in a work relationship (i.e. effort) and those that represent their outputs (i.e., job performance).

Allison Laura Cook (2008) in a research work with many potential causal models, explain this correlation, one possibility is that the satisfaction-performance relationship is actually spurious, advocating the correlation is due to common causes of both constructs. Common causes in this study include the job complexity and cognitive ability, in association with the personality traits, like Conscientiousness, Extraversion, Agreeableness, and core self-evaluations. The meta-analytic correlation matrix, through its structural equation modeling, suggests a residual correlation of .16 between job satisfaction and performance.

\section{Theoretical Background and Methodology}

\section{Theoretical Background}

The elements used to measure JS construct were adapted from Job Satisfaction Scale, developed by Amar Singh and TR Sharma. This scale has been designed specifically for workplace applications with a range of five dimensions, namely job intrinsic statements and job extrinsic statements. Job intrinsic statements are those factors inherent in the job, which includes job concrete statements such as excursions, places of posting, working conditions, etc and job abstract statements such as cooperation, democratic functioning, etc. Job extrinsic statements are those factors having no direct impact with the job, which includes Psycho-social factors such as intelligence and social circle, Economic factors such as salary and allowances, and finally the Community or National growth factors such as quality of life and contribution to the national economy.

Performance measurement scale is fulfilled with accurate and adequate emphasize on various personal, professional, general and extra attributes. The Professional attributes include Technical Competency, Skill level, Accuracy, Quality, Reliability, Learning Aptitude, Initiatives, Team Spirit, Sense of Duty and Drive \& Determination. Personal attributes consists of factors like Discipline, Honesty, Integrity, Loyalty, Punctuality, Politeness, Moral Ethics, Optimism, Behavioral Etiquettes and Trustworthy. The General attributes are Dress Code, Medical Fitness, Communication Skills, Computer Literacy and Disciplinary Cases. 


\section{Macrothink Institute ${ }^{T M}$}

The Extra attributes would get defined by employees' Education, Professional experiences, Additional achievements, Honors \& Awards, etc.

The JS Instrument Scale and the Self Assessment scale on Performance were given to the employees to record their self assessed score. Finally the JS score and the performance evaluation results are determined separately and then compared with each other. This comparison is made to find out the impact of JS factors on job performance of the employees and also in determining the relationship between these two factors. The theoretical model of this study is shown in figure 1.

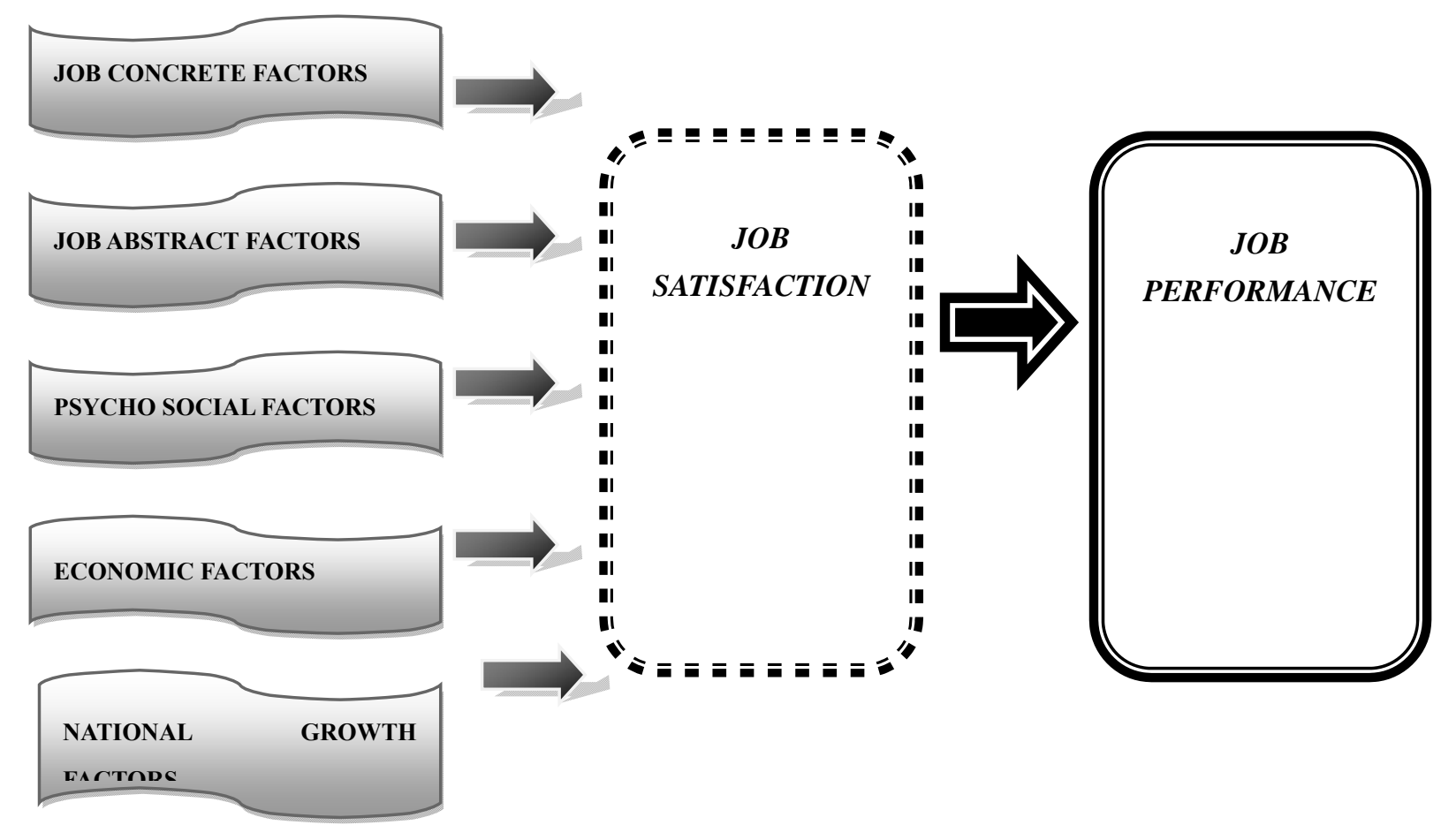

Source: Author's Construct (2016)

Figure 1. Conceptual framework on the impact of JS and its dimensions over the assessment of job performance

\section{Research Methods}

This is an exploratory research, attempting to discover how performance management process can be benefited in case of its integration with the perspectives of job satisfaction. The present research work adopts two grades of employees like Workers and Supervisors. Two questionnaires in the form of psychological tests were administered individually upon employees of Automobile Industry. The age, gender, nativity, organizational and educational status were controlled as subject relevant variables. The procedures, instructions, and administration were followed according to the respective test manuals.

\section{Data Collection}

The population chosen for this study is the supervisors and workers working in Automobile Industry in Jalandhar, Punjab. The sample size for this study was determined based on the 
rules of thumb in order to obtain reliable and valid results. Kline (2010) suggested that a sample of 200 or larger is suitable for a complicated path model when the population is large. The sample size of 250 respondents (Supervisors: 125 Nos., Workers: 125 Nos.) meets the recommended guidelines of Kline 2010. A convenience sampling method followed due to large population. Thus the respondents were selected on the basis of availability and willingness to participate in the survey.

In order to attain the goals of this study i.e. to measure the relationship between Job Satisfaction and its dimensions with the Job Performance level of the employees of the Automobile Industry, a questionnaire that measures the level of Job Satisfaction and its five dimensions were adopted. These constructs have been used and validated in previous studies and were adapted to local context to measure Job Satisfaction and performance. In addition, a number of demographic and background information had been collected. All the questions in the scales measuring the Job Satisfaction and its dimensions were scored on a five point Likert scale ranging from 1 (representing the strongest negative attitude towards the statement, ie, strongly disagree) to 5 (representing the most positive attitude towards the statement, ie, strongly agree). The demographic variables were all entered as categorical or ordinal values.

A self assessment measurement on performance Appraisal Scale was collected based on various important attributes of the respondents, where they were asked to give marks from 1 to 10 , representing maximum marks to be recorded is 10 . From the recorded self assessment marks of each respondent, a performance evaluation index is derived. It was assumed that the respondents whose mark falls lesser than 59 are considered as 'Below Average (BA)', between 60 to 69 as 'Average (AV)', from 70 to 79 as 'Above Average (AA)', from 80 to 89 as 'Excellent (EX)' and between 90 to 100 marks are considered as 'Out Standing (OS)'.

\section{Statistical Results}

\section{Demographic Data}

Table 1. Age of Respondents

\begin{tabular}{lcllll}
\hline Age & Frequency & Percentage (\%) & AV & AA & OS \\
\hline$<=30$ & 32 & 40 & 4 & 23 & 5 \\
$31-50$ & 44 & 55 & 8 & 20 & 16 \\
$>50$ & 4 & 5 & 0 & 1 & 3 \\
Total & 80 & 100 & 12 & 44 & 24 \\
\hline
\end{tabular}

Source: Researcher, September 2016.

It is noticed that almost (44) of the employees are having their performance level 'Above Average -AA' out of which (23) of the employees falls under the age group of lesser than or 
equal to 30 years, (20) of them falls under the age group of 31 to 50 years and (1) belongs to the age group of above 51 years. And about (12) of the employees are having their performance level 'Average -AV' out of which (4) of the employees falls under the age group of lesser than or equal to 30 years, (8) of them falls under the age group of 31 to 50 years. And there are (24) of the employees are having their performance level 'Outstanding -OS' out of which (5) of the employees falls under the age group of lesser than or equal to 30 years, (16) of them falls under the age group of 31 to 50 years and (3) belongs to the age group of above 51 years.

Table 2. Experience of Respondents

\begin{tabular}{llllll}
\hline Experience & Frequency & Percentage (\%) & AV & AA & OS \\
\hline$<10$ YEARS & 40 & 50 & 4 & 31 & 5 \\
$>10$ YEARS & 40 & 50 & 8 & 13 & 19 \\
Total & 80 & 100 & 12 & 44 & 24 \\
\hline
\end{tabular}

Source: Researcher, September 2016.

It is noticed that almost (44) of the employees are having their performance level 'Above Average -AA' out of which (31) of the employees having experience less than 10 years and (13) having experience more than 10 years. And about (12) of the employees are having their performance level 'Average $-\mathrm{AV}$ ' out of which (4) of the employees having experience less than 10 years and (8) of them having experience more than 10 years. And there are (24) of the employees are having their performance level 'Outstanding -OS' out of which (5) of the employees having experience less than 10 years and (19) of them having experience more than 10 years.

Table 3. Gender of Respondents

\begin{tabular}{llllll}
\hline Gender & Frequency & Percentage (\%) & AV & AA & OS \\
\hline Male & 52 & 65 & 8 & 25 & 19 \\
Female & 28 & 35 & 4 & 19 & 5 \\
Total & 80 & 100 & 12 & 44 & 24 \\
\hline
\end{tabular}

Source: Researcher, September 2016.

It is noticed that almost (44) of the employees are having their performance level 'Above Average $-\mathrm{AA}$ ' out of which (25) of the employees are male and (19) are female. And about (12) of the employees are having their performance level 'Average -AV' out of which (8) of the employees are male and (4) of them are female. And there are (24) of the employees are 
having their performance level 'Outstanding -OS' out of which (19) of the employees are male and (5) of them are female.

Table 4. Group of Respondents

\begin{tabular}{llllll}
\hline Group & Frequency & Percentage $(\%)$ & AV & AA & OS \\
\hline Supervisor & 40 & 50 & 3 & 21 & 16 \\
Worker & 40 & 50 & 9 & 23 & 8 \\
Total & 80 & 100 & 12 & 44 & 24 \\
\hline
\end{tabular}

Source: Researcher, September 2016.

It is noticed that almost (44) of the employees are having their performance level 'Above Average -AA' out of which (21) of the employees are Supervisor and (23) are Workers. And about (12) of the employees are having their performance level 'Average -AV' out of which (3) of the employees are Supervisor and (9) of them are Worker. And there are (24) of the employees are having their performance level 'Outstanding -OS' out of which (16) of the employees are Supervisor and (8) of them are Worker.

\section{Descriptive Statistics}

There is a Significance relationship and strong correlation between Job Satisfaction \& its dimensions and the performance evaluation of the employees of the Automobile Industry, Punjab. 


\section{Macrothink}

Journal of Management Research

ISSN 1941-899X

2017, Vol. 9, No. 1

Table 5. Correlation between Performance evaluation and Job Satisfaction \& its dimensions for Employees working in Automobile Industry

\begin{tabular}{|c|c|c|c|c|c|c|}
\hline $\begin{array}{l}\text { Pearson } \\
\text { Correlation }\end{array}$ & $\begin{array}{l}\text { Job } \\
\text { Intrinsic } \\
\text { Factor }\end{array}$ & $\begin{array}{l}\text { Job } \\
\text { Extrinsic } \\
\text { Factor }\end{array}$ & $\begin{array}{l}\text { Psycho } \\
\text { Socio } \\
\text { Factor }\end{array}$ & $\begin{array}{l}\text { Economic } \\
\text { Factor }\end{array}$ & $\begin{array}{l}\text { Community } \\
\text { /National } \\
\text { Factor }\end{array}$ & $\begin{array}{l}\text { Performance } \\
\text { Evaluation }\end{array}$ \\
\hline $\begin{array}{l}\text { Job Intrinsic } \\
\text { Factor }\end{array}$ & 1 & & & & & \\
\hline $\begin{array}{l}\text { Job } \\
\text { Extrinsic } \\
\text { Factor }\end{array}$ & $.604^{* *}$ & 1 & & & & \\
\hline $\begin{array}{l}\text { Psycho } \\
\text { Socio } \\
\text { Factor }\end{array}$ & $.484^{* *}$ & $.602^{* *}$ & 1 & & & \\
\hline $\begin{array}{l}\text { Economic } \\
\text { Factor }\end{array}$ & $.517^{* *}$ & $.583^{* *}$ & $.598^{* *}$ & $1^{* *}$ & & \\
\hline $\begin{array}{l}\text { Community } \\
\text { /National } \\
\text { Factor }\end{array}$ & $.286^{*}$ & $.519^{* *}$ & $.603^{* *}$ & $.451^{*}$ & $1^{* *}$ & \\
\hline $\begin{array}{l}\text { Performance } \\
\text { Evaluation }\end{array}$ & $.646^{* *}$ & $.781^{* *}$ & $.777^{* *}$ & $.690^{* *}$ & $.625^{* *}$ & $1^{* *}$ \\
\hline \multicolumn{7}{|c|}{$\begin{array}{l}\text { **. Correlation is significant at the } 0.01 \text { level (2-tailed). } \\
\text { *. Correlation is significant at the } 0.05 \text { level (2-tailed). }\end{array}$} \\
\hline
\end{tabular}

Source: Researcher, September 2016.

When Performance Evaluation was correlated with Job Satisfaction and its dimension, significant and positive correlation were found with Job Intrinsic Factor $(\mathrm{r}=0.646, \mathrm{p}<0.01)$, Job Extrinsic Factor $(r=0.781, p<0.01)$, Psycho Socio Factor $(r=0.777, p<0.01)$, Economic Factor $(r=0.690, p<0.01)$ and Community/National Factor $(r=0.625, p<0.01)$ at 0.01 levels of significance. Therefore, hypothesis that there exists significant relation between performance evaluation and Job Satisfaction and its dimension was strongly accepted. Hence, No 
significant correlation was obtained between performance and Job Satisfaction scores of Employees working in Automobile Industry, Punjab.

\section{Discussions and Implications}

Schultz D (2010) in their study advocates that job satisfaction is having a least significance in labours working in industries excluding construction industry. This study has been carried out to measure the level of job satisfaction among the employees working in automobile industry and also its impact on performance of these employees.

Markus Christen, Ganesh Iyer\& David Soberman (2006) in their study finds a positive, direct effect of job performance on job satisfaction. And Allison Laura Cook (2008) in their research explains the correlation between job satisfaction and job performance, which is due to common causes of both constructs. Common causes in this study include personality trait Conscientiousness, Extraversion, Agreeableness, and core self evaluations, along with cognitive ability and job complexity. There exists a significant relation between performance evaluation and Job Satisfaction and its dimension among the Employees working in Automobile Industry, Punjab.

In a survey conducted by Anuar Bin Hussin in a Trade winds Group of Companies, it was revealed that the dimensions of job satisfaction, like pay, promotion, work itself, supervision and co-workers have contributed 17.8 percent increase the job performance. Syaidatulakma binti bahani (2013) also articulated the same relationship between the aforesaid dimensions of job satisfaction and job performance.

Alina Hyz (2010) in their research observed that a well-educated employee has a lower state of satisfaction with respect to their salary. Other factors like recognition, autonomy, working with groups, prospects, clarity of responsibilities, relationships with co-workers and cooperation with the department of human resources show a positive correlation with job satisfaction with a considerable varying intensity. In a research conducted by Woodruffe \& Lockwood (2006), it was noticed that an engaged and satisfied employee having a good index of organizational commitment, would always tends to be the top performer of the organisation. Thus in this study there is a strong relationship between the Job satisfaction dimensions, like 'Job Intrinsic Factor' (0.646), 'Job Extrinsic Factor' (0.781), 'Psycho Socio Factor' (0.777), 'Economic Factor' (0.690) and 'Community/National Factor' (0.625) and job performance, regardless to their age, gender, job experience, group and level of employees working in the Automobile Industry, Punjab.

\section{Conclusion}

Organizations often neglect the impact of job satisfaction towards the gravity of employees' performance. This study explains how do the multiple dimensions of job satisfaction are evaluated and further correlated with the job performance of the employees among various groups in the Automobile industry. It was observed that there is a strong correlation between the levels of job satisfaction and of Performance of an employee, in both Supervisor and Worker groups of the Automobile Industry. Job satisfaction was observed higher in the supervisors' level rather than that of the Employees in workers level. It also indicates that 
employees with more job experience possess a higher degree of satisfaction than those with less job experience in the Automobile Industry in Punjab.

Since the main objective of this study is to investigate the impact of job satisfaction of the respondents on their performance level, it is detected that the former's impact over the latter are more in supervisor group who are holding higher ranks. Also a greater range of job satisfaction is uncovered in employees with more job experience rather than those with less experience. Besides to these, the study intends to find out the relationship between the job satisfaction factors and the performance evaluation results of the respondents. To this regard, the employees with more job satisfaction have indicated a higher performance evaluation score. Henceforth, developing a higher level of job satisfaction among the employees of an organization would, in turn help them to enhance their performance also.

Sooner or later, the measures can be adopted for a better performance management system in the organizations and can be incorporated with these specifics for future compliances. The idea behind this study is to give organizations an insight about the significance of job satisfaction with respect to the performance of its employees and how they can be leveraged to obtain the desirable results. Thus the results of this study may be experimented in other types of organizations also.

\section{References}

Agyare R, et.al. (2016). The Impacts of Performance Appraisal on Employees' Job Satisfaction and Organizational Commitment: A Case of Microfinance Institutions in Ghana. International Journal of Business and Management, 9(11). https://doi.org/10.5539/ijbm.v11n9p281

Bahani SKB. (2013). The relationship between job satisfaction and job performance: A case study of a Malaysian electronic organization.

Chadha, Narender K. (2005). Human Resource Management Issues, Delhi: Shri Sai Printographers.

Cook AL. (2008). Job satisfaction and job performance: Is the relationship spurious?

Gangai KN, \& Agrawal R. (2015). Job Satisfaction and Organizational Commitment: Is It important for Employee Performance. International Journal of Management and Business Research, 5(4), 269-278.

Hussin AB (2011). The relationship between job satisfaction and job performance among employees in trade winds group of companies.

Hyz A. (2010). Job satisfaction and employee performance of Greek banking staff: An empirical investigation.n

Indermun, V., \& Bayat MS. (2013). The job satisfaction -employee performance relationship: A theoretical perspective. International Journal of Innovative Research in Management, 2(11). 


\section{Macrothink}

Journal of Management Research

ISSN 1941-899X 2017, Vol. 9, No. 1

Judge TA, et. Al. (2001). The Job Satisfaction-Job Performance Relationship: A Qualitative and Quantitative Review. Psychological Bulletin, 3(127), 376-407.

Schultz, D., \& Schultz, S.E. (2010). Psychology and Work Today, Pearson Education, Inc.

Markus Christen, Ganesh Iyer, \& David Soberman. (2006). Job Satisfaction, Job Performance, and Effort: A Re-examination Using Agency Theory. Journal of Marketing, 70,137-150. https://doi.org/10.1509/jmkg.2006.70.1.137

Pushpakumari MD. (2008). The Impact of Job Satisfaction on Job Performance: An Empirical Analysis.

Ram P (2013). Relationship between Job Satisfaction and Job Performance in the Public Sector- A Case Study from India. International Journal of Academic Research in Economics and Management Sciences, 2(2).

Schultz, D., \& Schultz, S.E. (2010). Psychology and Work Today, Pearson Education, Inc.

Shmailan ASB. (2016). The relationship between job satisfaction, job performance and employee engagement: An explorative study. Issues in Business Management and Economics, $4(11)$. 